\title{
OPTIMUM WEIGHT TO WHICH PIGS SHOULD BE CARRIED FOR MAXIMUM PROFIT'
}

The swine industry in Puerto Rico to be profitable must be efficiently conducted. To that end, good stocks that convert feed efficiently are of economical importance. As swine make inefficient use of forage crops, highpriced concentrates have to be fed.

For that reason, and because the Agricultural Experiment Station has developed and made available a line of swine that is an efficient converter of concentrate feeds into pork, ${ }^{2}$ a table (table 1) has been devised to help determine the optimum weights to which such pigs should be carried for maximum profit under our conditions. This table will enable swine producers to estimate net profits from the enterprise before venturing into it. The table is a revision of previous ones. ${ }^{3}$

The data in the table covers feeding trials held from 1967 to 1969, which included 100 pigs of the $3 / 4$ Duroc X $1 / 4$ English Large Black Landrace line of pigs developed at this Station. ${ }^{4}$ The trials extended from weaning time on the 56th day to the 154th day of age of the animals. The pigs were weighed at weaning, at 70 days of age, and thereafter every 28 days until reaching 154 days of age. The average weaning weight was 30.18 pounds. The animals were fed ad libitum and the feed consumption recorded. Each group consisted of two females and two barrows. The groups were housed in $8 \times 10$ foot pens provided with automatic feeders and waterers.

The concentrate ration fed in all trials was mixed at the Lajas Substation's mixing unit. It contained approximately 15-percent crude protein, 3-percent crude fat, and 6.5-percent crude fiber.

The data collected was analyzed by using Mitscherlich's law of diminishing return as the relation between feed consumed and weight of the animals. The corresponding profit calculations were based on feed prices varying from $\$ 3.00$ to $\$ 5.50$ per hundredweight and a sale price for pigs of 15 to 31 cents per liveweight pound.

The overhead costs were disregarded in the calculations, although they are assumed to be approximately 20 percent of the total cost in swine production.

The average feed conversion of these pigs was 3.67 pounds of feed per pound of gain with an average daily weight gain of 1.73 pounds.

1 The authors thank Dr. Bernardo G. Capb for his assistance in the analysis of the data.

2 Carlo, I. and Arcelay, C. L., The development of a swine line for Puerto Rico, Agr. Exp. Sta. Mayagüez Campus, University of Puerto Rico, Bull. 193, May, 1965.

Carlo, I., Optimum weights to which pigs should be carried in Puerto Rico for maximum profits, J. Agr., Univ. P.R. 48 (1): 35-7, 1958.

- Carlo, I., and Arcelay, C. L., op. cit. 
TABLE 1.-Oplimum weights for maximum profits in $3 / 4$ Duroc $\times 1 / 4$ English Large Black Landrace pigs at the per pound selling price (liveweight) indicaled

\begin{tabular}{|c|c|c|c|c|c|c|c|c|c|c|c|c|c|c|c|c|c|c|}
\hline \multirow{3}{*}{$\begin{array}{c}\begin{array}{c}\text { Feed cost per } \\
100 \text { pounds }\end{array} \\
\text { Dollars }\end{array}$} & \multicolumn{18}{|c|}{ Selling price of liveweight pound of swine at- } \\
\hline & \multicolumn{2}{|c|}{$\$ 0.15$} & \multicolumn{2}{|c|}{$\$ 0.17$} & \multicolumn{2}{|c|}{$\$ 0.19$} & \multicolumn{2}{|c|}{$\$ 0.21$} & \multicolumn{2}{|c|}{ \$0.23 } & \multicolumn{2}{|c|}{$\$ 0.25$} & \multicolumn{2}{|c|}{$\$ 0.27$} & \multicolumn{2}{|c|}{$\$ 0.29$} & \multicolumn{2}{|c|}{ \$0.31 } \\
\hline & $F^{1}$ & $W^{2}$ & $F$ & $W$ & $F$ & $W$ & $F$ & $W$ & $\boldsymbol{F}$ & $W$ & $F$ & $W$ & $F$ & $\boldsymbol{W}$ & F & $W$ & $F$ & $\boldsymbol{W}$ \\
\hline 3.00 & 470 & 167 & 555 & 183 & 631 & 196 & 699 & 200 & 760 & 215 & 817 & 222 & 869 & 228 & 917 & 233 & 963 & 237 \\
\hline 3.25 & 416 & 156 & 501 & 173 & 576 & 187 & 044 & 198 & 706 & 203 & 703 & 215 & 815 & 221 & 863 & 227 & 908 & 232 \\
\hline 3.50 & 366 & 145 & 451 & 163 & 526 & 178 & 594 & 190 & 656 & 200 & 712 & 208 & 764 & 215 & 813 & 221 & 858 & 220 \\
\hline 3.75 & 319 & 134 & 404 & 153 & 479 & 169 & 547 & 182 & 609 & 193 & 665 & 201 & 718 & 209 & 766 & 215 & 811 & 221 \\
\hline 4.00 & 275 & 122 & 360 & 144 & 436 & 160 & 504 & 174 & 565 & 185 & 622 & 195 & 674 & 203 & 722 & 210 & 768 & 216 \\
\hline 4.25 & 234 & 111 & 319 & 134 & 395 & 151 & 462 & 166 & 524 & 178 & 581 & 188 & 633 & 191 & 681 & 204 & 726 & 210 \\
\hline 4.50 & 196 & 100 & 280 & 124 & 356 & 142 & 424 & 158 & 485 & 170 & 542 & 181 & 594 & 190 & 643 & 198 & 688 & 205 \\
\hline 4.75 & 159 & 88 & 244 & 114 & 319 & 134 & 387 & 150 & 449 & 163 & 505 & 174 & 557 & 184 & 606 & 192 & 651 & 199 \\
\hline 5.00 & 124 & 77 & 209 & 104 & 284 & 125 & 352 & 142 & 414 & 156 & 470 & 167 & 523 & 177 & 571 & 180 & 616 & 194 \\
\hline 5.25 & 91 & 60 & 176 & 94 & 251 & 116 & 319 & 134 & 381 & 148 & 437 & 161 & 490 & 171 & 538 & 180 & 583 & 188 \\
\hline 5.50 & 60 & 54 & 144 & 84 & 220 & 107 & 288 & 125 & 349 & 141 & 406 & 154 & 458 & 165 & 506 & 174 & 552 & 183 \\
\hline
\end{tabular}

$1 \mathrm{~F}=$ Feed consumed to reach maximum weight.

${ }^{2} \mathrm{~W}=$ Liveweight of the animal for maximum profits. 
The use of the table can be demonstrated for a hypothetical case in which feed will cost $\$ 3.50$ per 100 pounds and the pigs will sell for $\$ 0.21$ per pound of liveweight. A pig with a liveweight of 190 pounds that has consumed 594 pounds of feed from weaning to market time at a cost of $\$ 20.79$ will sell for $\$ 39.90$. If feed is estimated at 80 percent of the total cost of production, this cost can be calculated to be around $\$ 25.98$, which leaves a net profit of $\$ 13.92$ to the producer for this particular pig.

It must be stressed that the table is based on data obtained with animals of good heritage, consuming good quality feeds, and raised under efficient management. Under such conditions, feed costs may be lowered and net profits increased to overcome other expenses such as the value of the pigs as feeders or at weaning time. These factors are not included in these calculations. However, feeder pigs attain a market weight in about 3 months after weaning and this presents the possibility of marketing about four crops of pigs a year.

\author{
Ismael Carlo \\ Carlos L. Arcelay \\ Agricultural Experiment Station \\ College of Agricullure and Mechanic Arts \\ Mayagüez Campus \\ Universily of Puerlo Rico
}

